\begin{tabular}{cr}
\hline United Nations & A/RES/60/192 \\
\hline & \\
20 February 2006 & \\
2
\end{tabular}

\section{Resolution adopted by the General Assembly}

[on the report of the Second Committee (A/60)488/Add.1)]

60/192. International Year of Planet Earth

The General Assembly,

Reaffirming Agenda 21, the Plan of Implementation of the World Summit on Sustainable Development ("Johannesburg Plan of Implementation") and the Hyogo Framework for Action 2005-2015,

Noting that the wealth of scientific information available on planet Earth remains largely untapped and hardly known to the public or to policymakers and decision makers,

Convinced that education in Earth sciences provides humankind with tools for the sustainable use of natural resources and for building the scientific infrastructure essential for sustainable development,

Welcoming the decision of the General Conference of the United Nations Educational, Scientific and Cultural Organization to support the declaration of 2008 as the International Year of Planet Earth with a view to highlighting the importance of Earth sciences,

Taking into account the crucial role the Year could play, inter alia, in raising public awareness of the importance for sustainable develop- ment of the Earth's processes and resources; disaster prevention, reduction and mitigation; and capacity-building for the sustainable management of resources; and its important contribution to the United Nations Decade of Education for Sustainable Development,

1. Decides to declare 2008 the International Year of Planet Earth;

2. Designates the United Nations Educational, Scientific and Cultural Organization as the lead agency and the focal point for the Year to organize activities to be undertaken during the Year, in collaboration with the United Nations Environment Programme and other relevant entities of the United Nations system, as well as the International Union of Geological Sciences and other Earth science societies and groups throughout the world, and in this regard agrees that the activities of the International Year of Planet Earth will be funded from voluntary contributions, including, inter alia, from industry and major foundations mobilized by a consortium of international organizations, led by the International Union of Geological Sciences;

3. Encourages all Member States, the United Nations system and all other actors to take advantage of the Year to increase awareness of the importance of Earth sciences for the achievement of sustainable development and to promote action at the local, national, regional and international levels;

4. Requests the Secretary-General to report to the General Assembly at its sixty-second session on the progress of the preparations for the International Year of Planet Earth.

68th plenary meeting

22 December 2005

\section{UNESCO-IUGS Joint Statement Concerning the International Year of Planet Earth}

\section{November 2006, Paris}

The Director-General of the United Nations Educational, Scientific and CulturaI Organisation (UNESCO), Koïchiro Matsuura, and the President of the International Union of Geologica1 Sciences (IUGS), Zhang Hongren,

are pleased to announce the decision of the General Assembly of the United Nations to declare 2008 as the United Nations Year of Planet Earth,

and the designation by the United Nations of UNESCO as the lead agency, in collaboration with IUGS, in the implementation of the science and education activities during the International Year of Planet Earth.

They further,

Emphasize the great potential contribution of the International Year of Planet Earth to fulfil the Millennium Development Goals and to achieve the objectives of the UN Decade of Education for Sustainable Development, and

Consider that UNESCO, in successful partnersbip with IUGS in the international coordination of geoscience activities in general and particularly through their joint International Geoscience Programme (IGCP), provide excellent opportunities for cooperation between geoscientists worldwide.
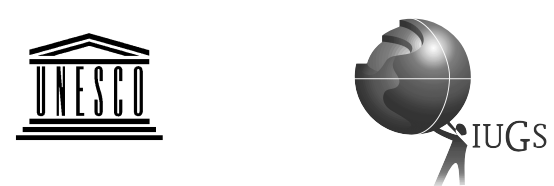

Convinced that financial contributions from industries, international organizations and foundations are crucial in the implementation of the activities during the International Year of Planet Earth, they,

Recognize that geosciences have made important progress in understanding the Earth processes over the past decades and that society should apply this knowledge for achieving a healthier, safer and more prosperous world for all,

Share the view that Earth Science for Society is an appropriate subtitle for the International Year of Planet Earth, as it highlights the equal importance of education, outreach and research activities during the Year, and

1. Encourage the geoscience community to take advantage of the International Year of Planet Earth to find satisfactory answers to future dangers faced by the Earth and to let society benefit from the opportunities provided by a sustainable use of the Earth's resources;

2. Invite intergovernmental, international, national and private space science organizations to make their observation systems available to support this initiative;

3. Encourage industries, international organizations and foundations to join and support this initiative to raise awareness and appreciation of the Earth as the ultimate resource for our everyday needs and the foundation of global society and economy. 